\title{
Use of the dialle analysis method in the study of the combination ability of insukht-lines of corn
}

Zaytsev S.A.

Russian Research Institute for Sorghum and Maize "Rossorgo", Saratov, Russia

E-mail: zea_mays@mail.ru

Key message. The results of the application of the diallelic analysis parameter are presented. The effects of GCA and dispersion of SCA were revealed. The components of genetic dispersion and the relative contribution of genes to the inheritance are reflected in the sign "grain yield"

Keywords: corn, yield, combining ability, genetic dispersion, effect

Evaluation of combinational ability allows you to select the source material and determine the possibility of using lines and hybrids. Goal. Detection of GCA and SCA of self-pollinated maize lines, as well as components of genetic dispersion, using the diallelic analysis method.

In the experiment, lines and simple hybrids (120 pcs.), Obtained by the diallelic scheme (method 2), were studied. The data were processed by analysis of variance, GCA and SCA - Griffing analysis, the components of the genetic dispersion were determined according to Hayman B.J.

The ranking by grain yield revealed a certain stability during the years of research of the CL 7, RSK3, Ch46, KS25 lines, and by the average group indicators showed relative stability in hybrids including the MK 11, RSK 7, RSK 3 lines in the pedigree maize, conducted by the diallelic scheme, indicate a low value of the effects of GCA on the basis of "grain yield" in the lines CL-7 (-0,13 ..- 0,61), Ch46 (-0,14 ..- 0,19). A high effect of GCA was noted in the following crosses: RSK 7 (0,12-0,27), MK11 (0,18-0,57), RSK 3 (0.28-0.49). High dispersion of SCA in different years was noted for lines RSK 3 (0,54-1,14), Bg $1266(0,43-1,60)$, PH26 (0,39-0,72), MK11 (0,24-0,70). Positive effects of SCA during the years of research were noted in the combinations MK 11/RSK 7 (0.41-0.98), MK 11/Yuv 19 (0.48-0.83), UK12D2/RSK 25 (0,36-0,75), UK12D2 / KS 25 (0,161,24), Ch46/KS 25 (0,25-1,87), CL-7 / RSK 3 (0,24-2,09), Yuv 19/Bg1266 (0,22-1,60), LV32/Od 28 (0,26-0,84).

In the experiment, there is a negative correlation between the value of the trait and the dominance of the parental lines: $0,601 \ldots-0,919$. Dominance is directed towards parental forms with a greater severity of the trait.

Significantly significant indicators of the components of dominance $\left(\mathrm{H}_{1}, \mathrm{H}_{2}\right.$.), in absolute value, exceed the values of component $\mathrm{D}$, which characterizes the additive effect of genes. The ratio $\sqrt{ } \mathrm{H} 1 / \mathrm{D}$ indicates the positive effect of overdomination $(3,16-7,12)$. The values of the $\mathrm{H} 2 / 4 \mathrm{H} 1$ ratio indicate a relatively uniform distribution of alleles with positive and negative effects. Depending on the growing conditions, the manifestation of grain yield is affected by 2-7 genes or groups of genes.

\section{Использование метода диаллельного анализа при изучении комбинационной способности инцухт-линий кукурузы} Зайцев C.A.

ФГБНУ Российский научно-исследовательский и проектно-технологический институт сорго и кукурузы «Россорго», Саратов, Россия

Аннотация. Представлены результаты применения метода диаллельного анализа. Выявлены эффекты ОКС и дисперсия СКС. Отражены компоненты генетической дисперсии и относительный вклад генов в наследование признака «урожайность зерна».

Ключевые слова: кукуруза, урожайность, комбинационная способность, генетическая дисперсия, эффект

Оценка комбинационной способности позволяет подобрать исходный материал и определить возможность использования линий и гибридов. Цель. Выявление ОКС и СКС самоопыленных линий кукурузы, а также компонентов генетической дисперсии, используя метод диаллельного анализа.

В опыте изучены линии и простые гибриды (120 шт.), полученные по диаллельной схеме (метод 2). Данные обработаны дисперсионным анализом, ОКС и СКС - анализом по Гриффингу, компоненты генетической дисперсии определяли по согласно Науman B.J.

Ранжирование по урожайности зерна выявило определенную стабильность в годы исследования линий CL 7, PCK3, Х46, КС25, а по среднегрупповым показателям выявило относительную стабильность у гибридов, включающих в родословную линии Мк 11, РСК 7, РСК 3. Результаты анализа ОКС и СКС самоопыленных линий кукурузы, проведенного по диаллельной схеме, указывают на низкое значение эффектов ОКС по признаку «урожайность зерна» у линий CL-7 (-0,13..-0,61), X46 (-0,14..-0,19). Высокий эффект ОКС отмечен у следующих компонентов скрещиваний: РСК 7 (0,12-0,27), Мк11 (0,18-0,57), РСК 3 (0,28-0,49). Высокая дисперсия СКС в разные годы отмечена у линий РСК 3 (0,54-1,14), Бг1266 (0,43-1,60), РН26 (0,39-0,72), Мк11 (0,24-0,70). Положительные эффекты СКС в годы исследования отмечены в комбинациях МК 11/РСК 7 (0,41-0,98), МК 11/ЮВ 19 (0,48-0,83), Ук12Д2/РСК 25 (0,36-0,75), Ук12Д2/КС 25 (0,16-1,24), Х46/КС 25 (0,25-1,87), CL-7/PCК 3 (0,24-2,09), ЮВ 19/Бг1266 (0,22-1,60), ЛВ32 /Од $28(0,26-0,84)$.

В опыте отмечается отрицательная корреляция между значением признака и доминированием у родительских линий: $-0,601 \ldots-0,919$. Доминирование направлено в сторону родительских форм с большей выраженностью признака.

Существенно значимые показатели компонентов доминирования $\left(\mathrm{H}_{1}, \mathrm{H}_{2}\right.$.), по абсолютной величине превышают значения компонента D, характеризующего аддитивное действие генов. Отношение $\sqrt{ } \mathrm{H}_{1} / \mathrm{D}$ свидетельствует о положительном влиянии сверхдоминирования $(3,16-7,12)$. Значения отношения $\mathrm{H}_{2} / 4 \mathrm{H}_{1}$ указывают на относительно равномерное распределение аллелей с положительными и отрицательными эффектами. В зависимости от условий выращивания, на проявление урожайности зерна влияют 2-7 генов или групп генов. 